Available online at website :

http://uinjkt.ac.id /index.php/elementar

Elementar (Elementary of Tarbiyah): Jurnal Pendidikan Dasar, 1(1), 2021, 22-37

\title{
Implementasi Problem Based Learning (PBL) dalam Pembelajaran Jarak Jauh di MI Al-Mursyidiyyah Selama Masa Pandemi
}

\author{
Celi Camelia ${ }^{1}$, Lu'luil Maknun ${ }^{2}$ \\ Pendidikan Guru Madrasah Ibtidaiyah, FITK, UIN Jakarta \\ J1. Ir H. Juanda No.95, Kota Tangerang Selatan \\ E-mail: celi.camelia19@mhs.uinjkt.ac,maknun@uinjkt.ac.id
}

\section{Corresponding}

Author: Celi Camelia1), Lu'luil Maknun'2)

Submit: 12 September 2020

Revisi: 22 Desember 2020

Approve: 20 Fubruari 2021

Pengutipan: Celi Camelia \& Lu'luil Maknun. (2021). Implementasi Problem Based Learning (PBL) dalam Pembelajaran Jarak Jauh di MI Al-Mursyidiyyah Selama Masa Pandemi. Elementar (Elementary of Tarbiyah): Jurnal Pendidikan Dasar, 1(1), 2021, 22-37. elementar.v1i1. 19649.

\section{Abstract}

The corona virus pandemic has spread throughout the world, and has an impact on all sectors of life, especially in the field of education. Distance learning is now an effective solution in the education system to reduce the spread of the corona virus. By examining the needs of all aspects of education, both the needs of educators and students in the form of facilities, infrastructure, learning models, learning methods, and so on. This research was conducted with the aim of examining the implementation of the Program Based Learning (PBL) based learning model at MI Al-Mursyidiyyah during distance learning. The research was conducted using a mixed method (combined research), as many as $43 \%$ of respondents applied the Program Based Learning (PBL) learning system in the learning process. Distance learning is considered quite easy to implement. The application of the Based Learning Program (PBL) is also considered quite effective for students in carrying out the distance learning process.

Keywords: Implementation, Learning, Problem Based Learning.

\begin{abstract}
Abstrak
Pandemi virus korona menyebar ke seluruh dunia, dan berdampak pada semua sektor kehidupan terutama di bidang pendidikan. Pembelajaran jarak jauh kini menjadi solusi efektif dalam sistem pendidikan untuk mengurangi penyebaran virus corona. Dengan mengkaji kebutuhan semua aspek pendidikan, baik kebutuhan pendidik maupun peserta didik berupa sarana, prasarana, model pembelajaran, metode pembelajaran, dan lain sebagainya. Penelitian ini dilakukan dengan tujuan untuk mengkaji implementasi model pembelajaran berbasis Program Based Learning (PBL) di MI Al-Mursyidiyyah selama pembelajaran jarak jauh. Penelitian dilakukan dengan menggunakan metode campuran (gabungan penelitian), sebanyak $43 \%$ responden menerapkan sistem pembelajaran Program Based Learning (PBL) dalam proses pembelajaran. Pembelajaran jarak jauh dinilai cukup mudah untuk dilaksanakan. Penerapan Program Pembelajaran Berbasis (PBL) juga dinilai cukup efektif bagi siswa dalam melaksanakan proses pembelajaran jarak jauh.
\end{abstract}

Kata kunci: Implementasi, Pembelajaran, Problem Based Learning. 


\section{PENDAHULUAN}

Pendemi virus covid-19 masih marak terjadi diseluruh dunia, termasuk di Indonesia. terlihat kasus pandemi virus covid-19 terus menerus mengalami kenaikan. Pandemi virus ini memberikan banyak sekali dampak bagi seluruh sektor, seperti sektor perekonomian, sektor pemerintahan, sektor pendidikan, dan masih banyak lagi. Pemerintah perlu melakukan suatu hal yang dapat mengurangi penyebaran virus covid-19 ini agar tidak melonjak dan menyebar dengan cepat. Hal ini membuat pemerintah mengeluarkan kebijakan-kebijakan untuk mengurangi atau memutus rantai penyebaran virus corona. Kebijakan yang dibuat pemerintah bukan hana memperhatikan bidang kesehatan namun juga berbagai bidang perlu bekerjasama unutk memberantas virus covid-19 ini. Kebijakan yang diterapkan oleh pemerintah yaitu penerapan Pembatasan Sosial Berskala Besar (PSBB) sampai pada penutupan beberapa sektor, yaitu sektor pendidikan. Sejak bulan Maret 2020 sampai Oktober 2020 pemerintah menutup sekolah baik di tingkat TK (Taman Kanak-kanak), SD (Sekolah Dasar), SMP (Sekolah Menengah Pertama), SMA (Sekolah Menengah Atas), bahkan Perguruan tinggi. Penutupan sekolah ini membuat proses belajar mengajar yang semula tatap muka berubah menjadi sistem daring (online).

$$
\text { Pembelajaran Jarak Jauh (PJJ) }
$$
merupakan hal baru yang dilakukan untuk siswa dikarenakan pandemi yang belum juga usai. Selama pandemi covid-19 belum berakhir, maka pembelajaran tatap muka yang dilakukan secara normal seperti biasa, nampaknya sulit untuk dilakukan. Pembelajaran ini dilaksanakan dengan memanfaatkan teknologi baik di tingkat SD, SMP, SMA, maupun Perguruan Tinggi. Untuk tingkat MI/SD khususnya didampingi oleh orang tua dirumah. Dengan pembelajaran daring ini mendapat keleluasaan siswa dalam melakukan proses pembelajaran, karena dapat berlangsung dimanapun dan kapanpun (Dewi, 2020). Hal ini menunjukkan salah satu kelebihan dalam pembelajaran jarak jauh.

Selain itu, pembelajaran jarak jauh dengan menggunakan teknologi juga memiliki kelebihan lain diantaranya, yaitu: 1) Belajar bermakna, 2) Memudahkan siswa mengakses informasi dari berbagai sumber dan referensi terpercaya (tidak terpusat pada guru), dan 3) Peningkatan terhadap hasil belajar. Hal ini dikarenakan siswa MI/SD lebih berperan aktif dan mulai mengenal dunia teknologi. Berinteraksi dengan gambar, video, suara, dan lain sebagainya (Khasanah et al., 2020). Kegiatan belajar tersebut dapat membantu siswa selama belajar di rumah. Namun, bersamaan dengan itu, pembelajaran jarak jauh pun memiliki tantangan tersendiri baik untuk guru (pendidik), siswa (peserta didik), dan orangtua. Dengan ini, dapat kita 
ketahui bahwa dalam pelaksanaan pembelajaran yang dilakukan secara daring tentunya terdapat pula kekurangankekurangan yang terjadi.

Apabila kita telaah mengenai perkembangan ilmu pendidikan dan teknologi di Indonesia masih berkembang. Maka dalam sektor pendidikannya negara Indonesia masih banyak yang harus dibenahi kualitasnya (Fuadi \& Muchson, 2020). Terlebih, dimasa pandemi ini yang merasakan kesulitan dalam menjalankan proses pembelajaran bukan hanya guru atau siswa tetapi keduanya sedang belajar bersama berkolaborasi dalam proses pembelajaran agar tujuan pembelajaran dapat tercapai. Hal ini tentu menjadi tantangan bagi guru, siswa, dan orang tua yang berperan dalam siklus pendidikan. Guru dituntut untuk beradaptasi dengan pembelajaran basis teknologi yang sebelumnya dilaksanakan secara langsung (tatap muka). Guru terus mencari dan melakukan inovasi untuk membuat strategi belajar yang aktif dan inovatif bagi siswa.

Namun, masalah baru muncul ketika pembelajaran daring dilakukan menggunakan teknologi seperti gawai tidak semua anak memiliki sendiri. Banyak yang melakukan pembelajaran online dengan ibu, kakak, atau adiknya karena kegiatan yang semula dilakukan tanpa teknologi yang ada di rumah, kini hal tersebut menjadi kendalanya. Siswa juga sering merasa kesulitan untuk memahami materi yang disampaikan oleh guru. Maka dari itu, dimasa pandemi ini guru dituntut agar mampu menciptakan suasana belajar yang aktif, kreatif, dan inovatif.

Tetapi, dalam pembelajaran jarak jah ini cukup banyak kesulitanyang dirasakan oleh guru, siswa, bahkan orang tua. Guru kesulitan dalam mengelola pembelajaran, waktu pembelajaran yang berkurang namun harus sesuai dengan ketentuan. Bagi orang tua permasalahannya ialah berkomunikasi dengan guru, dan kesulitan dalam mendampingi beberapa anak. Serta kendala dari siswa yaitu sulitnya untuk konsentrasi saat belajar dirumah, selain itu siswa hany diberikan beban tugas saja oleh guru. Maka perlu adanya kerjasama yang baik antara guru, orang tua, dan siswa di rumah. Dengan ini, guru diberikan pelatihan dalam mengelola kelas atau metode dan model pembelajaran supaya siswa tetap aktif, kreatif. Sehingga PJJ ini dapat berjalan dengan sesuai dengan tujuan dan harapan.

Hal ini selaras dengan kepmendikbud No. $719 / \mathrm{P} / 2020$ tentang Pedoman Pelaksanaan Kurikulum pada Satuan Pendidikan dalam Kondisi Khusus, menyatakan bahwa pembelajaran meski dalam kondisi khusus (pembelajaran daring) tetap dilaksanakan secara aktif, partisipatif, inklusif, keragaman budaya, berorientasi pada masa depan, sesuai dengan kemampuan serta kebutuhan siswa, dan belajar yang menyenangkan (Kemdikbud, 2020a). Berdasarkan hal tersebut peserta didik juga 
diharapkan mampu berperan dalam proses pembelajaran secara aktif, kreatif, dan inovatif. Untuk itu, guru memberikan pelajaran bukan hanya menuntut siswanya untuk aktif tetapi juga mampu untu berperan dalam kegiatan pembelajaran, bertanya, mengeluarkan saran atau pendapat, mengamati, menimpulkan, dan lain sebagainya. Dengan ini pastinya guru melakukan berbagai macam model pembelajaran bagi siswanya. Penyesuaian kondisi siswa tersebut tentunya memerlukan model pembelajaran yang tepat agar siswa dapat berpikir terbuka dan mampu mengontruksi pengetahuan yang pelajarinya, sehingga bukan hanya sekadar teori saja yang didapat. Jika hal ini tidak terpenuhi maka pembelajaran jarak jauh akan menurunkan kualitas anak-anak sekolah (Kemdikbud, 2020b)

Salah satu model pembelajaran sesuai dengan kriteria tersebut adalah dengan menerapkan sistem pembelajaran Problem Based Learning (PBL) (Kaharuddin, 2019). Problem based learning atau pembelajaran berbasis masalah ini lebih mengaktifkan siswa dalam mencari solusi sesuai dengan permasalahan yang disajikan oleh guru. Dalam pembelajaran ini guru dituntut untuk berperan sebagai fasilitator, kemudian siswa yang mencari, mencermati, menyimpulkan, mengeluarkan hipotesis atau pendapat, mengeluarkan ide dan gagasan, dan lain sebagainya (Kemdikbud, 2020a).
Hasil penelitian yang dilakukan Abdullah dan Ridwan menyatakan bahwa pembelajaran berbasisi masalah dapat meningkatkan kemampuan kognitif, afektif, dan psikomotorik (Nafiah \& Suyanto, 2014). Kemampuan kognitid merupakan kemampuan siswa dalam mengonstruksi pembelajaran yang ia lakukan dengan menggunakan kinerja otak. Afektif merupakan penerapan pembelajaran yang diserap melalui tindakan yang berupa nilainilai sikap yang ada dalam kehidupan, sedangkan psikomotorik adalah kemampuan yang dimiliki oleh masing-masing siswa. Untuk itu perlu adanya model pembelajaran yang tepat agar seluruh siswa mampu untuk mengembangkan kemampuan yang ada dalam dirinya.

Berdasarkan latar belakang yang telah dipaparkan, maka penelitian ini bertujuan untuk mengetahui implementasi Problem Based Learning (PBL) yang dilakukan secara daring/online dapat terealisasi dengan baik. Selain itu, untuk mengetahui kesesuaian dengan target atau tujuan pembelajaran selama pandemi di MI Al-Mursyiddiyah. Implementasi problem based learning diharapkan dapat melatih siswa untuk berpikir kritis. Berpikir kritis termasuk kedalam keterampilan dasar siswa dalam mengembangkan kegiatan belajar mengajar yang dilakukan dengan menarik dan menggunakan metode pembelajaran yang mendukung pada situasi tersebut. Proses 
Implementasi Problem Based Learning (PBL) Dalam Pembelajaran Jarak Jauh...

pembelajaran jarak jauh dengan menggunakan model pembelajaran Problem Based Learning (PBL) dapat meningkatkan proses berpikir siswa untuk memecahkan permasalahan secara sistematis. Dalam memecahkan masalah dimulai dari bentuk

\section{METODE}

Penelitian ini dilaksanakan di MI AlMursyidiyyah yang terletak didaerah Tangerang Selatan dengan menggunakan penelitian Gabungan (Mix Method). Metode penyajian data menggunakan kualitatif deskriptif melalui kajian pustaka/literature, sedangkan teknik analisis data menggunakan teknik kuantitatif melalui kuesioner.

Penelitian ini dilakukan dengan menggunakan metode kualitatif dan literatur research pada sebuah jurnal, artikel, dan lain sebagainya. Metode kualitatif merupakan pengambilan data yang menghasilkan data deskriptif yang dijabarkan melalui kata-kata terhadap suatu perilaku yang terjadi. Pengumpulan data dilakukan berdasarkan pendekatan untuk dapat memahami suatu permasalahan secara alami dan holistik (utuh). Penelitian yang terjadi dengan menggunakan langkah-langkah pengamatan seperti pengamatan, wawancara, menganalisis data (Subandi, 2011). Hal ini subjek penelitian ditentukan berdasarkan pertimbangan sesuai dengan aturan yang ditetapkan peneliti yaitu seorang pendidik atau guru yang mengajar di MI Al-Musyidiyyah. Metode kualitatif dipilih pertanyaan-pertanyaan

lemudian menemukan solusi, mengumpulkan informasi, mendiskusikan hasil pengumpulan informasi, dan merefleksikan hasil diskusi (Buheji \& Buheji, 2020).

berdasarkan kebutuhan untuk menganalisis permasalahan dalam penelitian dengan menggali informasi dari pihak responden (Tobing et al., 2016). Dalam penelitian secara kualitatif digali berdasarkan latar belakang atau kenyataan.

Desain penelitian dilakukan dengan mengisi survey sederhana yang diisi oleh sebanyak 27 orang tenaga pendidik (guru) yang mengajar diseluruh bidang mata pelajaran mengisi data kuesioner yang telah diberikan. Kemudian, penulis melakukan kajian terhadap kasus yang diteliti, yaitu mengenai model pembelajaran Problem Based Learning (PBL).

Kemudian sumber data yang kedua dilakukan dengan cara literatur research. Variabel yang terdapat dalam studi pustaka memang tidak bersifat baku, namun dalam penelitiannya harus dilakukan dengan teliti. Pengumpulan data pada studi pustaka bukan saja hanya membaca banyak jurnal atau literatur, melainkan dengan membaca, mencatat hal-hal penting, dan mengolah hasil peneltiian studi pustaka tersebut (Melfianora, 2019). 


\section{HASIL DAN PEMBAHASAN}

Pada pembelajaran jarak jauh di MI AlMursydiyyah kondisi pembelajaran terpaksa dilakukan secara daring. Dengan penerapkan sistem pembelajaran online, guru mengajar dengan menggunakan teknologi informasi. Strategi pembelajaran yang dilakukan secara daring ini merupakan hal baru yang didapatkan. Tenaga pendidik menerapkan sistem pembelajaran yang serba menggunakan teknologi informasi, sehingga perlu menyiapkan metode pembelajaran yang berbeda.

\section{Pembelajaran Jarak Jauh}

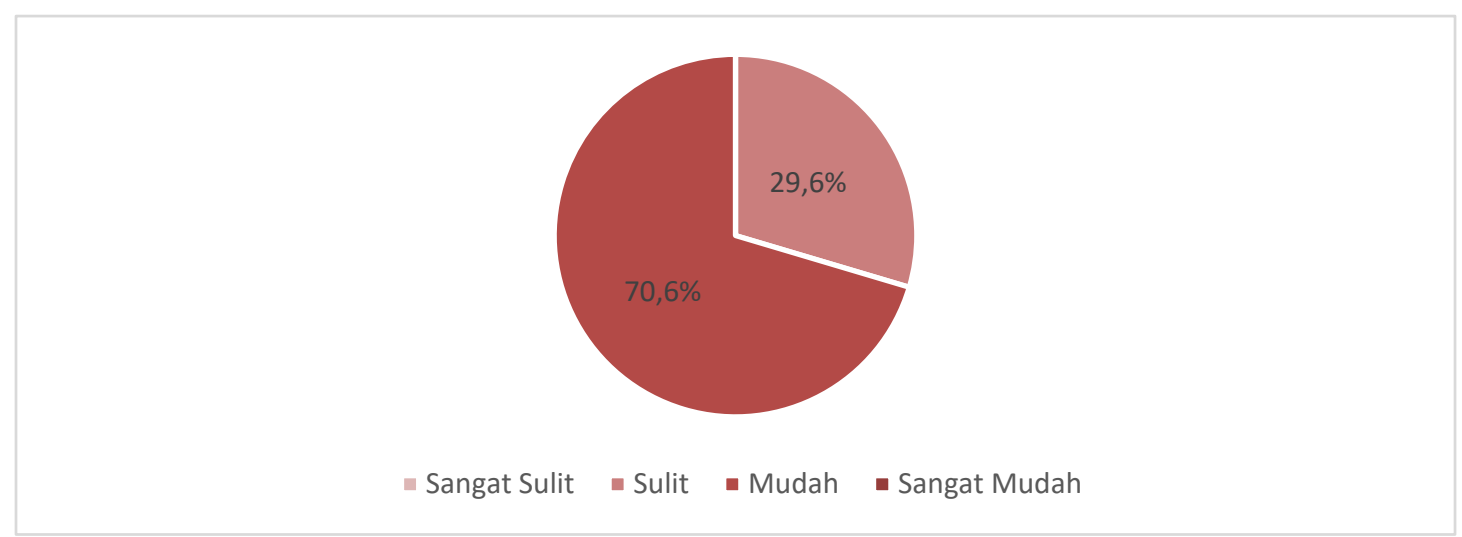

Gambar 1. Pembelajaran Jarak Jauh (PJJ)

Berdasarkan 27 responden sebanyak 70,4\% menyatakan bahwa pembelajaran jarak jauh dinilai cukup mudah untuk dilaksanakan. Sedangkan 29,6\% lainnya menyatakan sulit. Hal ini pastinya disebabkan oleh berbagai faktor. Selama melakukan pembelajaran jarak jauh tidak mengalami kesulitan yang berarti. Namun, pasti ada yang mengalamibeberapa hambatan atau gangguan yang terjadi pada saat menjalankan prosesnya. Hal ini tentunya menjadi bahan evaluasi untuk seluruh tenaga pendidik agar pembelajaran jarak jauh dapat diperbaiki, sehingga siswa mendapatkan pembelajaran yang sesuai.

Responden menyatakan pula selama pembelajaran melalui daring ini dilakukan, tenaga pendidik pun melakukan berbagai macam metode dan model pembelajaran. Melalui pemanfaatan teknologi, guru mencoba berbagai macam metode pembelajaran dengan memanfaatkan platform yang tersedia secara online. Selain itu, guru juga membuat media pembelajaran sebagai bentuk inovasi yang dilakukan selama pembelajaran jarak jauh. Media yang biasa digunakan oleh para pendidik diantaranya yaitu pembelajaran dengan memberikan video dari Youtube, membuat power point, membuat modul pembelajaran, Quiziz, dan mencoba berbagai platform terbaru lainnya. Hal ini dilakukan untuk membuat para siswa agar tetap aktif dan partisipatif dalam melaksanakan PJJ ini. Meskipun harus dilakukan secara daring. Tentunya hal ini menjadi tantangan tersendiri untuk para tenaga pendidik agar terus melakukan berbagai inovasi. Namun, hal ini tidak 
sepenuhnya dapat berjalan dengan mulus. Pastinya selalu ada tantangan dan hambatan.

Hambatan dan Solusi dalam Pembelajaran Jarak Jauh (PJJ)

Pembelajaran jarak jauh yang dilakukan saat ini pastinya jauh dari kata sempurna. Banyak sekali hambatan dan tantangan yang dirasakan, baik oleh guru, orang tua, dan tentunya untuk siswa. Hambatan ini terdiri dari beberapa faktor tentunya yang berkaitan dengan teknis pembelajaran. Dapat diketahui bahwa pembelajaran daring ini dilakukan dengan memanfaatkan teknologi dan informasi seperti HP (handphone). Maka, tenaga pendidik harus memanfaatkan hal tersebut dengan sebaikbaiknya dalam menyampaikan materi pembelajaran. Hambatan yang sering ditemukan dalam sistem daring ini mulai dari terbatasnya kuota data dan sinyal, penugasan yang terlalu banyak, sampai pada kesulitan siswa dalam memahami materi yang disampaikan oleh guru. Karena keterbatasan dalam melakukan proses pembelajaran yang menyebabkan siswa kesulitan dalam memahami materi.

Metode pembelajaran secara daring yang dilakukan oleh para tenaga pendidik supaya siswa tetap aktif dalam mengikuti pembelajaran, hendaknya mengarahkan siswa agar dapat merealisasikan hasil pembelajarannya dalam kehidupan sehari-hari. Hal yang berkaitan dengan kehidupan sehari-hari siswa pastinya akan lebih memudahkan siswa untuk mengerjakan setiap tugas yang diberikan.

Namun, selain itu ada yang lebih penting bagi siswa selain harus mendapatkan haknya untuk belajar dan belajar. Siswa juga hendaknya diberikan kesempatan untuk mengembangkan minat dan bakatnya. Selain memberikan materi dala rangka pengembangan kognitif siswa tetapi guru juga harus mampu dalam memberikan pembelajaran yang dapat melatih afektif dan psikomotorik pada siswa. Hal ini tentunya membutuhkan model pembelajaran yang tepat dimasa pandemi covid-19 ini. Model pembelajaran yang dapat mencakup pengembangan kognitif, afektif, dan psikomotorik. Pada sistem pembelajaran di sekolah dasar menerapkan sistem belajar secara Tematik. Pengaplikasian pembelajaran tematik dapat meningkatkan hasil belajar siswa dalam dimensi karakter, keterampilan, serta pengetahuan. Jadi sangat di perlukan model pembelajaran yang tepat bagi siswa MI/SD (Chumdari et al., 2018).

Atas dasar hal tersebut maka penelitian ini dilakukan berdasarkan hasil pengumpulan data-data kuesioner yang telah diisi. Serta mengkaji teori yang berkaitan dengan model pembelajaran yang tepat sebagai solusi dalam bentuk implementasi kegiatan pembelajaran jarak jauh. Dalam hasil survey yang telah dilakukan dalam bentuk tes kepada tenaga pendidik dapat diketahui bahwa dari 21 responden hampir semuanya sudah melakukan pembelajaran aktif kepada siswa. Mulai dari sistem blended learning, project based learning, bahkan 7 diantaranya telah menerapkan pembelajaran problem based learning. Hal yang menjadi fokus peneliti dalam penelitian ini adalah mengenai model pembelajaran problem based learning.

Seperti yang sudah banyak diketahui bahwa model pembelajaran problem based learning ini meliputi kegiatan aktif yang dilakukan oleh siswa. Kegiatan tersebut berupa mencari 
informasi, analisis, dan lain sebagainya untuk memecahkan masalah yang diberikan oleh guru. Implementasi pembelajaran problem based learning telah dilaksanakan oleh beberapa para tenaga pendidik di MI Al-Mursyidiyah. Pembelajaran berbasis proyek ini selain mudah dilaksanakan tetapi juga sangat simple dan menarik bagi siswa. Kemampuan siswa dikembangkan dengan cara yang mudah dan efektif sehingga siswa tidak merasa bahwa dirinya sedang dilatih atau diajarkan untuk mengembangkan potensi kognitif, afektif, dan psikomotoriknya. Model pembelajaran pemecahan masalah tentunya memberikan banyak pertanyaan untuk siswa yang membuat siswa ingin mencari berbagai informasi untuk memecahkan masalah tersebut. Keinginan dan motivasi tersebut merupakan hal yang posif sebagai solusi ditengah pandemi dengan banyaknya hambatan-hambatan yang terjadi. Maka dari itu, hal ini menyebabkan siswa merasa senang dalam belajar. Dapat diketahui dari hasil penelitian melalui survey yang dilakukan di MI AlMursyidiyyah menyatakan bahwa:

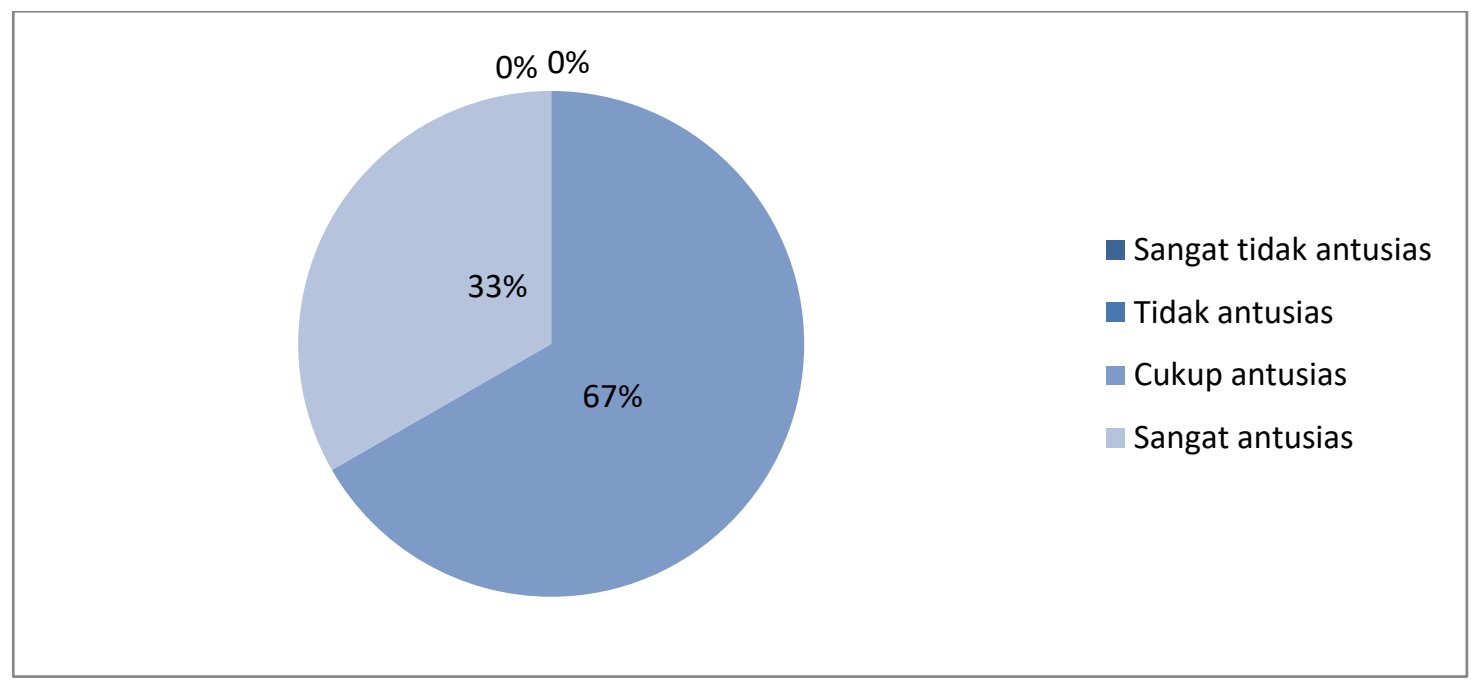

Gambar 2. Antusias dan Semangat dalam melakukan pembelajaran Online

Jumlah antusiasme tenaga pendidik dalam melakukan pembelajaran terlihat sangat baik. Saat guru dapat dengan antuasias dan semangat dalam melakukan proses pembelajaran diharapkan mampu untuk memberikan pembelajaran yang terbaik. Proses pembelajaran yang dilakukan oleh tenaga pendidik dilakukan

\section{Pembahasan}

$$
\text { Problem Based Learning (PBL) }
$$
merupakan suatu model pembelajaran yang menggunakan metode secara langsung atau yang disebut dengan kontekstual. Model pembelajaran ini didasarkan pada suatu permasalahan yang dengan berbagai macam cara. Salah satunya ialah dengan menerapkan model Problem Based Learning (PBL). Hal ini menunjukkan bahwa pembelajaran problem based learning mudah untuk dilakukan dan tidak menyulitkan bagi guru maupun siswa.

membutuhkan identifikasi untuk memecahkan masalah tersebut (WIJOYO \& INDRAWAN, 2020). Dengan mengidentifikasi sebuah masalah dapat meningkatkan daya pikir siswa. Selain itu, peran guru bukan hanya sebagai fasilitator yang 
menyediakan sumber bahan ajar tetapi juga mengarahkan siswa dalam memecahkan suatu masalah. Guru memberikan suatu permasalahan yang sesauai dengan kemampuan siswa dan bersifat nyata, agar siswa tidak merasa kesulitan namun pembelajaran yang disampaikan dapat mencapai tujuan.

Pembelajaran jarak jauh merupakan suatu hal yang baru dilakukan serempak seluruh Indonesia, bahkan negara luar. Pandemi covid-19 belum juga mereda, sehingga segala kegiatan yang berkaitan dengan kontak langsung terhadap orang sekitar. Termasuk di sekolah, kini guru harus melakukan kegiatan proses belajar mengajar dirumah. Guru dapat memanfaatkan platform yang tersedia untuk menunjang kegiatan belajar mengajar yang dilakukan. Menurut Herliandy, pembelajaran online adalah transfer ilmu pengetahuan melalui video, gambar, audio, komunikasi berupa teks, dan lain sebagainya (Herliandry et al., 2020). Sebagai bagian generasi dari revolusi industri memang sudah seharusnya terbiasa berinteraksi dengan segala hal yang berbasis teknologi. Terlebih, dalam pembelajaran jarak jauh ini menuntut para peran pendidik untuk menyesuaikan kebutuhan belajar siswa. Kebutuhan tersebut mencakup aspek pembelajaran yang meliputi pengetahuan, moral, keterampilan, kecerdasan, dan estetika (Herliandry et al., 2020). Namun, selain materi dan soal siswa juga membutuhkan konsep belajar yang lebih matang untuk merangsang kebutuhan belajar siswa. Hal ini berkaitan dengan strategi pembelajaran yang meliputi model pembelajaran, metode pembelajaran, dan media pembelajaran.

Dalam temuan ini pembelajaran jarak jauh yang dilaksanakan pada sekolah dasar tentu memerlukan kerjasama yang baik dengan orangtua. Menurut Ismail (Dewina et al., 2017) pembelajaran jarak jauh utamanya memerlukan jaringan internet dengan adanya akses jaringan maka hambatan-hambatan dalam menjalankan proses pembelajaran jarak jauh dapat diminimalisir. Dalam masa pandemi yang terjadi saat ini pembelajaran tetap bisa dilakukan dengan menggunakan teknologi melalui video conference, google from, ataupun grup whatsapp. Berdasarkan penelitian yang dilakukan di MI AlMursyidiyyah yang menyatakan bahwa pembelajaran jarak jauh dapat dilakukan dengan cukup mudah hal ini selaras dengan hasil penelitian yang dilakukan oleh Dewi yang menyatakan bahwa implementasu pembelajaran daring yang dilakukan akibat dampak dari covid19 dapat dilakukan dengan baik. Hal ini bergantung pada efektifitas dan kreatifitas guru dalam memberikan materi dan soal-soal latihan yang dikerjakan oleh siswa sebagai nilai hariannya. Pada masa pandemi ini guru memberikan berbagai macam model pembelajaran untuk siswa diantaranya, yaitu Projek Based Learning, Blended Learning, Portofolio, dan Problem Based Learning. Diantara keempat model pembelajaran tersebut pastinya memiliki kekurangan dan kelebihan masing-masing pada penerapannya dimasa pandemi covid-19 ini.

Projek based learning atau pembelajaran berbasis proyek mengarahkan siswa untuk membuat suatu hal cenderung lebih mengarahkan siswa pada pengembangan keterampilan psikomotorik siswa. Blended learning merupakan model pembelajaran klasik atau tradisional yang diterapkan dalam pembelajaran jarak jauh. Penerapan model blended learning dapat 
dilakukan dengan sumber belajar secara online diantaranya yaitu berbasis web (Indriani et al., 2018).

Terakhir yaitu problem based learning yang menjalankan proses pembelajaran berbasis masalah. Dalam pelaksanaannya problem based learning berpusat pada keaktifan siswa. Dalam hal ini proses pembelajaran jarak jauh data berlangsung lebih kompleks. Tidak hanya pengembangan kognitifnya saja yang ditekankan, tetapi menyeluruh. Hal inilah yang menjadi perbedaan pembelajaran berbasis masalah diterapkan dalam proses pembelajaran jarak jauh.

1. Konsep Pembelajaran Problem Based Learning dalam Proses Pembelajaran Jarak Jauh (PJJ).

Dalam pelaksanaan proses pembelajaran jarak jauh problem based learning menghadirkan sesuatu yang berbeda bagi siswa. Pembelajaran ini dapat menumbuhkan rasa keingintahuan siswa terhadap pemaslaahan yang disajikan. Kemudian mereka akan terdorong untuk melakukan suatu pergerakan untuk memecahkan masalah tersebut. PBL memberikan kesempatan bagi para siswa untuk membangun pemahamannya secara lebih koheren, sistematis, dan fleksibel. Hal ini didukung oleh pernyataan Ard and Lee (Kris \& Hidayatulloh, 2020) yang menyatakan bahwa pengaplikasian problem based learning sebagai model pembelajaran melalui tahapan metode saintifik dapat mengembangkan pengetahuan sekaligus keterampilan dalam memecahkan masalah.

Pembelajaran Problem Based Learning (PBL) telah diakui oleh WHO (World Health Organization) sebagai pola pembelajaran yang tepat untuk mengajarkan pembelajaran yang dilaksanakan dengan kerjasama (Marshall et al., 2008). PBL adalah proses belajar di mana peserta melakukan tahapan-tahapan mengenai informasi apa saja yang harus didapat untuk memecahkan suatu masalah yang disajikan. Hal itu membuat siswa terjun langsung untuk mencari solusi terhadap masalah yang dihadapi oleh siswa dalam kehidupan sehari-hari. Dengan proses pembelajaran mandiri siswa dapat meneliti masalah yang dihadapi. Namun, pembelajaran problem based learning ini dapat dilakukan secara berkelompok. Model problem based learning dapat meningkatkan kemampuan siswa dalam berinteraksi dan sosial. Karena untuk mememcahkan sebuah masalah, siswa harus berinteraksi atau berdiskusi, sehingga terjadi pembelajaran kolaborasi yang tercipta dalam pembelajaran problem based learning. Pendekatan model pembelajaran problem based learning meningkatkan pemikiran yang kritis terhadap pemecahan suatu masalah. Berikut merupakan manfaat model pembelajaran Problem Based Learning (PBL):

a. Meningkatkan kemampuan berpikir kritis

Berdasarkan hasil penelitian meta-anaisis yang dilakukan dengan model pembelajaran problem based learning (PBL) menyatakan siswa dapat berpikir kritis apabila diberikan pembelajaran yang dapat merangsang pola berpikir siswa. Salah satu caranya ialah dengan memberikan pembelajaran berbasis masalah. Daya pikir siswa pastinya akan berbeda-beda, tetapi dengan menerapkan pembelajaran problem based learning dapat merangsang daya berpikir siswa menjadi lebih kritis. Hal ini terjadi karena keinginan untuk memecahkan suatu masalah yang 
disajikan oleh guru. Berdasarkan hasil penelitian Anugraheni dengan menggunakan model pembelajaran Problem Based Learning (PBL) mampu meningkatkan sedikitnya 2,87\% sampai $33,56 \%$ daya berpikir kritis bagi siswa. Hal ini mengalami peningkatan yang cukup signifikan. Sehingga pembelajaran problem based learning ini bersifat kompleks (Anugraheni, 2018).

b. Meningkatkan kemampuan analisis dan berargumentasi

Pada proses pembelajaran problem based learning (PBL) bersifat student centered Dalam hal ini guru hanya bersifat sebagai fasilitator kemudian guru memberikan permasalahan yang ada dalam kehidupan seharihari sesuai dengan indikator materi siswa. Siswa berperan aktif dalam menganalisis setiap pemecahan masalah. Guru berperan sebagai pemberi tanggapan atau memberi solusi terhadap masalah yang ada. Namun, siswa yang mencari akar permasalahan dan solusinya dengan menganalisis permaslahan tersebut secara sistematis dan terstruktur. Hal ini dapat meningkatkan kemampuan siswa dalam menganalisis suatu masalah dengan baik. Siswa juga berpikir kritis dan analitik untuk mencari kesimpulan dari permasalahan yang terjadi. Sehingga dengan menggunakan model pembelajaran problem based learning (PBL) siswa diharapkan mampu memotivasi dalam kegiatan pembelajaran terutama saat melakukan pembelajaran jarak jauh (PJJ). Dengan penggunaan sistem pemecahan masalah siswa merasa tertantang dan lebih bersemangat dalam mengerjakan tugas yang diberikan. Hal tersebut tentunya meningkatkan kemampuan menganalisis dan keterampilan berargumentasi (Dewina et al., 2017).

$$
\begin{aligned}
& \text { c. Meningkatkan kemampuan } \\
& \text { memecahkan masalah }
\end{aligned}
$$

Berdasarkan hasil observasi yang terangkum dalam penelitian Handayani (2016) mendapatkan hasil bahwa peningkatan kemampuan memecahkan masalah pada siswa. Peningkatan kemampuan ini dikarenakan dalam proses pembelajaran Problem Based Learning (PBL) rumusan masalah yang diteliti telah terstruktur. Selain itu, tujuan pembelajaran dan masalah yang disuguhkan selaras dengan kehidupan sehari-hari (Handayani \& Sopandi, 2016). Dalam pemecahan masalah siswa melakukan langkah-langkah yang mampu mengajarkan siswa memecahkan masalah secara efektif dan efisien. Kemudian, siswa juga melakukan pengkajian terhadap suatu sumber informasi yang mereka dapatkan. Maka dari itu, melatih siswa dalam memilih masalah dan sumber pemecahan masalah yang tepat.

Manfaat proses pembelajaran Problem Based Learning (PBL) ini sangat banyak jika dilakukan secara optimal dan sesuai. Pada masa pandemi ini tentunya beberapa hal terhambat untuk dilaksanakan dalam pembelajaran. Namun, hal tersebut bukanlah halangan untuk tetap membuat siswa aktif dan partisipatif dikelas. Meskipun kelas tersebut dilakukan secara daring. Pembelajaran Problem Based Learning diharapkan mampu untuk meningkatkan siswa kompetensi peserta didik selama belajar dirumah. Hal ini dilakukan agar siswa mendapatkan suatu tantangan sehingga semangatnya terpacu untuk menyelesai misi yang berbentuk maslaah tersebut. Pembelajaran berbasis proyek melibatkan tugas 
yang berhubungan dnegan penelitian, penyelidikan, analisis, dan aktif. Dalam pembelajarannya melatih kecakapan siswa dalam memecahkan masalah.

Pada masa pandemi ini para siswa melakukan pembelajaran secara daring sehingga pada setiap pembelajarannya siswa pasti menggunakan internet. Pembelajaran berbasisi proyek atau Problem Based Learning (PBL) ini menjadi salah satu solusi dalam pelaksanaan pembelajaran yang dilakukan secara online. Siswa tidak serta merta hanya mencari jawaban yang ada di internet, namun mereka harus melakukan analisis terhadap jawaban atau mencari solusi secara nyata (Abidin et al., 2020). Pembelajaran online ini dapat dimanfaatkan oleh para tenaga pendidik untuk melakukan inovasi pembelajaran dengan berbasis proyek. Karena dalam pembelajaran online ini banyak sekali platform yang mendukung untuk memberikan pengajaran untuk peserta didik. Pelaksanaan proses pembelajaran dengan Problem Based Learning (PBL) yang dilakukan saat Pembelajaran Jarak Jauh (PJJ) dinilai cukup banyak manfaatnya bagi siswa.

\section{Implementasi Model Pembelajaran Problem Based Learning (PBL) dalam Pembelajaran Jarak Jauh (PJJ)}

Berdasarkan hasil penelitian melalui kuesioner sebanyak 66,7\% menyatakan bahwa cukup antusias dan bersemangat dan 33,3\% menyatakan sangat antusias dan bersemangat dalam melakukan pembelajran decara daring atau online. Dengan menggunakan media dan tools yang bermacam-macam hal ini terlihat bahwa implementasi model pembelajaran Problem Based Learning (PBL) dapat diterapkan dengan baik. Kemampuan menganalisis siswa dan proses belajar yang dilakukan tidak terasa seperti sedang belajar. Namun, hal itu dapat mengembangkan kemampuan siswa secara tidak langsung untuk berpikir kritis, menganalisa, mengidentifikasi, dan lain sebagainya. Implementasi pembelajaran dengan menggunakan model Problem Based Learning ini dapat meningkatkan hasil belajar siswa dengan baik. Cara penerapan problem based learning ini dengan memberikan langkahlangkah pengenalan masalah pada siswa, mengorganisasi pemecahan sebuah masalah sebagai proses belajar, membantu mengidentifikasi baik individu maupun kelompok, mengembangkan sekaligus menganalisis suatu proses yang terjadi dalam pemecahan masalah tersebut (Kaharuddin, 2019). Berdasarkan penemuan dari hasil penelitian survey yang dilakukan menyatakan bahwa pembelajaran jarak jauh dengan menggunakan berbagai macam model pembelajar cukup antuasias. Beberapa guru telah menerapkan sistem pembelajaran berbasis masalah pada peserta didik saat pembelajaran jarak jauh. Hasil yang didapatkan juga membawa banyak pegaruh positif bagi siswa yang melaksanakan pembelajaran. Untuk itu implemebtasi pembelajaran problem based learning dianggap cukup efektif digunakan saat pembelajaran dilakukan secara online. 
Implementasi Problem Based Learning (PBL) Dalam Pembelajaran Jarak Jauh...

\section{SIMPULAN}

Pandemi covid-19 ini telah menghambat proses pembelajaran yang terjadi dalam pendidikan terutama di sekolah dasar. Namun, di MI Al-Mursyidiyyah proses Pembelajaran Jarak Jauh (PJJ) dirasa cukup mudah untuk dilaksanakan dalam pembelajaran. Selain itu, pendidik dan peserta didik juga cukup senang dalam dalam melakukan pembelajaran se cara online. Implementasi pembelajaran dengan menggunakan model Problem Based Learning (PBL) dirasa cukup efektif. Model pembelajaran Problem Based Learning (PBL) memiliki manfaat sebagai berikut:

a. Meningkatkan kemampuan berpikir kritis

\section{REFERENCES}

Abidin, Z., Rumansyah, \& Arizona, K. (2020). Pembelajaran Online Berbasis Proyek Salah Satu Solusi Kegiatan Belajar Mengajar Di Tengah Pandemi Covid-19. Jurnal Imiah Profesi Pendidikan, 5(1), 64-70. https:// doi.org/10.29303/JIPP.V5I1.111

Anugraheni, I. (2018). Meta Analisis Model Pembelajaran Problem Based Learning dalam Meningkatkan Keterampilan Berpikir Kritis di Sekolah Dasar. Polygot, 14(1), 9-18. http://dx.doi.org/10.19166/pji.v14i1.789

Buheji, M., \& Buheji, A. (2020). Characteristics of 'Problem-Based Learning' in Post-COVID19 Workplace. Human Resource Management Research, 10(2), 33-39. https://doi.org/10.5923/j.hrmr.20201002. 02

Chumdari, C., Sri Anitah, S. A., Budiyono, B., \& b. Meningkatkan kemampuan analisis dan berargumentasi

c. Meningkatkan kemampuan memecahkan masalah

Implementasi pembelajaran berbasis masalah dapat membantu siswa dalam perkembangan kognotif, afektif, dan psikomotorik. Dengan memecahkan sebuah masalah akan menimbulkan pertanyaan untuk siswa yang membuat mereka menggali, menganalisis, dan mengidentifikasi suatu masalah yang telah disajikan. Dalam rangka pengembangan kemampuan yang dimiliki oleh siswa maka pembelajaran dengan model Problem Based Learning cukup efektif digunakan pada masa pandemi Covid-19 ini

Nunuk Suryani, N. (2018). Implementation of Thematic Instructional Model in Elementary School. International Journal of Educational Research Review, 3(4), 23-31. https://doi.org/10.24331/ijere.424241

Dewi, W. A. F. (2020). Dampak COVID-19 terhadap Implementasi Pembelajaran Daring di Sekolah Dasar. Edukatif: Jurnal Ilmu Pendidikan, 2(1), 55-61. https://doi.org/10.31004/edukatif.v2i1.89 Dewina, S., Suganda, O., \& Widiantie, R. (2017). Pengaruh Model Pembelajaran Problem Based Learning (Pbl) Terhadap Kemampuan Menganalisis Dan Keterampilan Berargumentasi Siswa Pada Konsep Pencemaran Lingkungan Di Kelas X. Quagga: Jurnal Pendidikan Dan Biologi, 9(02),

53. 
https://doi.org/10.25134/quagga.v9i02.74 8

Fuadi, A. S., \& Muchson, M. (2020). Penerapan Model Pembelajaran Problem Based Learn Ing ( Pbl ) Pada Masa Pandemi Covid 19 Dalam Meningkatkan Aktivitas Dan Kewirausahaan. Seminar Nasional Manajemen, Ekonomi, Akuntansi, 5(1), 23-33. https://proceeding.unpkediri.ac.id/index.p $\mathrm{hp} /$ senmea/article/view/225

Handayani, D., \& Sopandi, W. (2016). Penggunaan Model Problem Based Learning untukMeningkatkan Kemampuan Memecahkan Masalah dan Sikap Peduli Lingkungan Peserta Didik. EduHumaniora | Jurnal Pendidikan Dasar Kampus Cibiru, 7(2), 105.

https://doi.org/10.17509/eh.v7i2.2702

Herliandry, L. D., Nurhasanah, Suban, M. E., \& Heru, K. (2020). Pandemic learning during the Covid-19. Jurnal Teknologi Pendidikan, 22(1), 65-70. https://doi.org/https://doi.org/10. 21009/jtp.v22i1.15286

Indriani, T. M., Fathoni, T., \& Riyana, C. (2018). Implementasi Blended Learning Dalam Program Pendidikan Jarak Jauh Pada Jenjang Pendidikan Menengah Kejuruan. Edutcehnologia, 2(2), 129-139.

Kaharuddin, A. (2019). Effect of Problem Based Learning Model on Mathematical Learning Outcomes of 6th Grade Students of Elementary School Accredited B in Kendari City. International Journal of Trends in Mathematics Education Research, 1(2), 43-46. https://doi.org/10.33122/ijtmer.v1i2.14

Kemdikbud. (2020a). Kepmendikbud Nomor
719/P/2020 tentang Pedoman Pelaksanaan Kurikulum pada Satuan Pendidikan dalam Kondisi Khusus. Www.Kemdikbud.Go.Id, 022651 , 9. https://www.kemdikbud.go.id/main/blog /2020/08/kemendikbud-terbitkankurikulum-darurat-pada-satuanpendidikan-dalam-kondisi-khusus

Kemdikbud. (2020b). Penyesuaian Kebijakan Pembelajaran di Masa Pandemi Covid-19. Www.Kemdikbud.Go.Id, 26. https://www.kemdikbud.go.id/main/blog /2020/08/kemendikbud-terbitkankurikulum-darurat-pada-satuanpendidikan-dalam-kondisi-khusus

Khasanah, D. R. A. U., Pramudibyanto, H., \& Widuroyekti, B. (2020). Pendidikan Dalam Masa Pandemi Covid-19. Jurnal Sinestesia, 10(1), 41-48. https:// sinestesia.pustaka.my.id/journal/ar ticle/view/44

Kris, M., \& Hidayatulloh, Y. (2020). THE EFFECT OF PROBLEM-BASED LEARNING MODEL AND BLENDED LEARNING MODEL TO METACOGNITIVE AWARENESS. $26(2)$ 183-188. https://doi.org/10.21831/jptk.v26i2.3278 3

Marshall, C. S., Yamada, S., \& Inada, M. K. (2008). Using problem-based learning for pandemic preparedness. Kaohsiung Journal of Medical Sciences, 24(3 SUPPL.), 39-45. https://doi.org/10.1016/S1607$551 \mathrm{X}(08) 70093-7$

Melfianora. (2019). Penulisan Karya Tulis Ilmiah dengan Studi Literatur. Open Science 
Implementasi Problem Based Learning (PBL) Dalam Pembelajaran Jarak Jauh...

Framework, 1-3. osf.io/efmc2

Nafiah, Y. N., \& Suyanto, W. (2014). Penerapan model problem-based learning untuk meningkatkan keterampilan berpikir kritis dan hasil belajar siswa. Jurnal Pendidikan Vokasi, $\quad 4(1), \quad$ 125-143. https://doi.org/10.21831/jpv.v4i1.2540

Subandi. (2011). Deskripsi Kualitatif Sebagai Satu Metode Dalam Penelitian Pertunjukan.
Harmonia - Journal of Arts Research and

Education, 11(2), 173-179. https://doi.org/10.15294/harmonia.v11i2. 2210

Tobing, D. hizki, Herdiyanto, Y. K., \& Astiti, D. P. (2016). Bahan Ajar Metode Penelitian Kualitatif. Program Studi Psikologi Fakultas Kedokteran Universitas Udaya, 42. 